\title{
DIFFERENCES IN MORPHOLOGICAL CHARACTERISTICS AND MOTOR ABILITIES BETWEEN SLOVENIAN AND SERBIAN MALE GYMNASTS
}

\section{ROZDÍLY MEZI SLOVINSKÝMI A SRBSKÝM GYMNASTY V TĚLESNÝCH PROPORCÍCH, POHYBOVÝCH SCHOPNOSTECH A DOVEDNOSTECH}

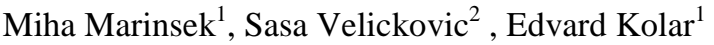 \\ ${ }^{1}$ Faculty of Education Maribor, Slovenia, ${ }^{2}$ Faculty for Sports and Physical Education Nis, Serbia
}

\begin{abstract}
The purpose of this present research was to find out the differences in morphological characteristics and motor abilities between slovenian and serbian gymnasts. We tested 100 male gymnasts from slovenia and serbia who were seven to fourteen years of age and were at the time of testing competing for at least two years. We classified gymnasts into four different age groups according to the competition system. Gymnasts who were 7 years of age ( 3 from each country), 9 - 10 years of age ( 20 from each country), 11 - 12 years of age (17 from each country), 13 - 14 years of age (10 from each country). All gymnasts agreed on performing the tests. We found out that statistically significant differences between slovenian and serbian gymnasts exist in 19 out of 35 variables and are mostly in favour of slovenian gymnasts. We think that slovenian gymnasts performed most of the tests better mainly because of the longer tradition of top-level gymnastics. Serbian experts should concider to incorporate expert and research advanced study courses for serbian coaches into their training system.
\end{abstract}

Key words: gymnastics, morphological characteristics, motor abilities, Slovenia, Serbia

\section{SOUHRN}

Cílem studie bylo zjistit rozdíly mezi slovinskými a srbskými gymnasty $\mathrm{v}$ tělesné stavbě, v pohybových schopnostech a dovednostech. Testování se zúčastnilo 100 slovinských a srbských gymnastů mužského pohlaví ve věku od sedmi do čtrnácti let, kteří v době měření se nejméně dva roky účastnili soutěží. $\mathrm{V}$ souladu se soutěžním systémem byli závodníci rozděleni do čtyř kategorií (kategorie sedmiletých 3 osoby z každé země, kategorie 9 - 10-ti letých 20 osob z každé země, kategorie 11 - 12-ti letých 17 osob z každé země a kategorie 13 - 14-ti letých 10 osob z každé země). Zúčastnění souhlasili s prováděným měřením. Zjistili jsme statisticky významné rozdíly v 19-ti z 35-ti proměnných, většinou ve prospěch slovinských gymnastů. Domníváme se, že lepší výsledky dosažené slovinskými gymnasty jsou podmíněny hlavně delší tradicí vrcholové gymnastiky v této zemi. Srbští odborníci by měli zvážit začlenění odborníků a výsledků výzkumu do nadstavbových kurzů srbských trenérů a tím i do jejich tréninkového systému.

Klíčová slova: gymnastika, tělesná stavba, pohybové schopnosti, Slovinsko, Srbsko

For the competitive sport the selection process is highly important. It is important that we select children for the certain sport discipline who have all the necesary predispositions for achieving their competative goal. Every sport discipline has its own demands in morphologic characteristics, motor, functional and other abilities. For every sport discipline, a perfect type of competitor exists, who can represent the model for selection - the model of a champion. The process of selection in gymnastics is based on assessment of the model's characteristics which are dominant and have a significant influence on gymnast's outcome.

Slovenian gymnastics school has developed a battery of tests for young gymnasts which enables a successful assessment of gymnast's perspectivness. The battery has been developed upon practical knowledge, long lasting observations and 
longitudinal studies.

Cuk, Kolar and Piletic (1997) started to develope the project for the new competition system for young slovenian gymansts. The competition system consists of:

- compulsory exercises for each age group

- assessment of technical knowledge

- assessment of morphological characteristics

- assessment of motor abilities

The gymnasts are devided in four age groups:

- $\quad$ first category from 6 to 8 years

- second category from 9 to 10 years

- $\quad$ third category from 11 to 12 years

- fourth category from 13 to 14 years

The potential efficiency of the gymnast is assessed on the basis of results for the single test (Cuk, Kolar, Crnjac and Piletic, 1997; Crnjac, 1998). The potential efficiency helps coaches with their planning and to compare their gymnasts with others.

The goal of this research is to find differences in morphological characteristics and motor abilities between young slovenian and serbian gymnasts.

\section{Method}

\section{Subject}

We tested young serbian and slovenian male gymnasts who were seven to fourteen years of age and were at the time of testing competing for at least two years. The following number of gymnasts was tested: 6 gymnasts 7 years of age (3 from each country), 40 gymnasts $9-10$ years of age (20 from each country), 34 gymnasts $11-12$ years of age (17 from each country), 20 gymnasts $13-14$ years of age (10 from each country). All together we assessed 100 gymnasts (50 from each country).

Slovenian gymnasts represented six different clubs and serbian gymnasts five different clubs in their country. These are all the clubs that are involved in top-level male gymnastics in both countries. Thus our subjects represent characteristics of the whole countries.

\section{Measures}

For the assessment of morphological characteristics and motor abilities we used different number of tests for each age groupe (Table 1).
For the assessment of morphological characteristics we used the following variables:

ATV - body height

ATT - body weight

AKGN - upper arm skin fold

For the assessment of motor abilities we used the following general tests:

PON - obstacle course backwards

TAP - hand tapping

SDM - standing broad jump

PRE - forward bench fold

DT - 60-second sit-ups

VES - bent arm hang

For the assessment of specific motor abilities we used the following specific tests:

PLEZN - rope climbing $5 \mathrm{~m}$ with help of the legs (6-8 years)

PLEZBN - rope climbing $5 \mathrm{~m}$ without help of the legs (9-14 years)

OPOKR - support on the rings (6-8 years)

PREKR - L sit on the rings (9-10 years)

VAGZ - back lever on the rings (9-10 years)

VAGS - front lever on the rings (11-14 years)

NAUTEZ - vertical pull up with bent arms to support on the rings (9-10 years)

VZN - V sit on parallelbars (9-10 years)

KOLJU - double leg circles on the mushroom (6-8 years)

KOLOK - double leg circles in cross-support on the horse without pommels facing to the other end of the horse (9-10 years)

KOLOR - double leg circles on the pommels (1112 years)

CKOL - double leg circles in cross-support on the pommel horse facing away from the pommels (1314 years)

STOJAST - handstand with stomach to the wall (68 years)

STOJABR - handstand on the parallel bars (9-10 years)

STOJ - handstand on the floor (11-12 years)

STOJKR - handstand on the rings (13-14 years)

SPIBRA - press to handstand on the parallel bars (9-12 years)

SPIKR - press to handstand on the rings (13-14)

SKLEBR - push-ups in support on the parallel bars (6-8 years)

Table 1. Number of tests for each age group (Cuk and Kolar, 1999)

Tabulka 1. Počet testů v každé věkové skupině (Cuk and Kolar, 1999)

\begin{tabular}{|l|c|c|c|c|}
\hline \multicolumn{1}{|c|}{ age groupe } & morphological ch. & general tests & special strength & special flexibility \\
\hline first category & 3 & 5 & 5 & 5 \\
\hline second category & 3 & 5 & 8 & 5 \\
\hline third category & 3 & 5 & 8 & 5 \\
\hline fourth category & 3 & 5 & 7 & 5 \\
\hline
\end{tabular}


Table 2. Descriptive statistics and $t$ test between Slovenian and Serbian gymnasts 6 - 8 years of age Tabulka 2. Výsledky t-testu u jednotlivých položek ve věkové skupině $6-8$ let gymnastů Slovinska a Srbska

\begin{tabular}{|c|c|c|c|c|c|c|}
\hline TEST & COUNTRY & MEAN & STD & STD ERROR & T VALUE & SIG. T \\
\hline \multirow[t]{2}{*}{ ATV } & Slovenia & 1284.33 & 91.00 & 52.54 & \multirow{2}{*}{1.818} & \multirow{2}{*}{.143} \\
\hline & Serbia & 1180.00 & 40.00 & 23.09 & & \\
\hline \multirow[t]{2}{*}{ ATT } & Slovenia & 256.67 & 43.39 & 25.05 & \multirow{2}{*}{1.74} & \multirow{2}{*}{.157} \\
\hline & Serbia & 203.33 & 30.55 & 17.64 & & \\
\hline \multirow[t]{2}{*}{ AKGN } & Slovenia & 57.33 & 11.37 & 6.57 & \multirow{2}{*}{1.77} & \multirow{2}{*}{.151} \\
\hline & Serbia & 43.33 & 7.57 & 4.37 & & \\
\hline \multirow[t]{2}{*}{$\mathrm{PON}$} & Slovenia & 97.33 & 13.50 & 7.80 & \multirow{2}{*}{-1.07} & \multirow{2}{*}{.342} \\
\hline & Serbia & 115.33 & 25.58 & 14.77 & & \\
\hline \multirow[t]{2}{*}{ TAP } & Slovenia & 27.33 & 2.52 & 1.45 & \multirow{2}{*}{-.13} & \multirow{2}{*}{.900} \\
\hline & Serbia & 27.67 & 3.51 & 2.03 & & \\
\hline \multirow[t]{2}{*}{ SDM } & Slovenia & 175.33 & 6.11 & 3.53 & \multirow{2}{*}{8.58} & \multirow{2}{*}{.001} \\
\hline & Serbia & 143.33 & 2.08 & 1.20 & & \\
\hline \multirow[t]{2}{*}{ PRE } & Slovenia & 56.00 & 5.29 & 3.06 & \multirow{2}{*}{.00} & \multirow{2}{*}{1.00} \\
\hline & Serbia & 56.00 & 4.58 & 2.65 & & \\
\hline \multirow[t]{2}{*}{ DT } & Slovenia & 48.67 & 3.51 & 2.03 & \multirow{2}{*}{3.39} & \multirow{2}{*}{.027} \\
\hline & Serbia & 39.00 & 3.46 & 2.00 & & \\
\hline \multirow[t]{2}{*}{ VES } & Slovenia & 61.00 & 9.54 & 5.51 & \multirow{2}{*}{-3.78} & \multirow{2}{*}{.019} \\
\hline & Serbia & 85.67 & 6.03 & 3.48 & & \\
\hline PLEZN & Slovenia & 140.33 & 44.81 & 25.87 & & \\
\hline & Serbia & 139.00 & 19.08 & 11.02 & .04 & .964 \\
\hline OPOKR & Slovenia & 49.33 & 1.15 & .67 & 1024 & $0 \cap 0$ \\
\hline & Serbia & 13.67 & 5.86 & 3.38 & 10.34 & . .000 \\
\hline KOLJU & Slovenia & 38.33 & 12.01 & 6.94 & 160 & 184 \\
\hline & Serbia & 19.00 & 17.06 & 9.85 & 1.00 & .184 \\
\hline STOJAST & Slovenia & 100.00 & .00 & .00 & & \\
\hline & Serbia & 100.00 & .00 & .00 & $\mathrm{a}$ & $\mathrm{a}$ \\
\hline SKLEBR & Slovenia & 20.00 & .00 & .00 & 68 & 532 \\
\hline & Serbia & 16.33 & 9.29 & 5.36 & .08 & .532 \\
\hline MOST & Slovenia & 98.33 & 10.41 & 6.01 & 20 & 851 \\
\hline & Serbia & 100.00 & 10.00 & 5.77 & -.20 & .851 \\
\hline MSP & Slovenia & 1.00 & 1.00 & .58 & -168 & 168 \\
\hline & Serbia & 5.00 & 4.00 & 2.31 & -1.68 & .168 \\
\hline ŽSPL & Slovenia & .33 & .58 & .33 & -148 & 213 \\
\hline & Serbia & 4.67 & 5.03 & 2.91 & -1.48 & .213 \\
\hline ŽSPD & Slovenia & .67 & 1.15 & .67 & -106 & \\
\hline & Serbia & 4.00 & 5.29 & 3.06 & -1.06 & .346 \\
\hline
\end{tabular}

a... $\mathrm{t}$ cannot be computed because the standard deviations of both groups are 0 .

From the table 1 we can confirm statistically significant differences between mean values for the test SDM and OPOKR $(\mathrm{p}<0.01)$ and for the test DT and VES $(\mathrm{p}<0.05)$. Slovenian gymnasts are better in leg power (SDM), statical power of arms and shoulders (OPOKR) and muscular endurance of the torso (DT). Serbian gymnasts are better in muscular endurance of shoulder girdle and arms (VES) (Table 2).

\section{Procedure}

All gymnasts agreed on performing the tests and they warmed up before they proceeded to the measurements. They were all assesed on the same day. The execution of the tests was performed acorrding to the predetermined rules (Cuk and Kolar, 1999).

The data were analysed using the SPSS 12.0 statistical package. We calculated the descriptive and comparative statistics.
For the descriptive statistics we used the following measures:

mean value - MEAN

standard deviation - STD

standard error - STD ERROR

For the comparative statistics we used $\mathrm{T}$ test for small independent samples:

value of the $\mathrm{T}$ test $-\mathrm{T}$ VALUE

significance of the T test - SIG. T 
Table 3. Descriptive statistics and $t$ test between Slovenian and Serbian gymnasts 9 - 10 years of age Tabulka 3. Výsledky t-testu u jednotlivých položek ve věkové skupině 9 - 10 let gymnastů Slovinska a Srbska

\begin{tabular}{|c|c|c|c|c|c|c|}
\hline TEST & COUNTRY & MEAN & STD & \begin{tabular}{|l|} 
STD ERROR \\
\end{tabular} & T VALUE & SIG. T \\
\hline \multirow[t]{2}{*}{ ATV } & Slovenia & 1342.20 & 55.88 & 12.50 & \multirow{2}{*}{1.516} & \multirow{2}{*}{.138} \\
\hline & Serbia & 1317.20 & 48.09 & 10.75 & & \\
\hline \multirow[t]{2}{*}{ ATT } & Slovenia & 282.00 & 75.75 & 16.94 & \multirow{2}{*}{-.218} & \multirow{2}{*}{.829} \\
\hline & Serbia & 285.95 & 29.18 & 6.52 & & \\
\hline \multirow[t]{2}{*}{ AKGN } & Slovenia & 55.70 & 14.08 & 3.15 & \multirow{2}{*}{1.395} & \multirow{2}{*}{.171} \\
\hline & Serbia & 49.50 & 14.03 & 3.14 & & \\
\hline \multirow[t]{2}{*}{ POL } & Slovenia & 75.50 & 18.35 & 4.10 & \multirow{2}{*}{-4.105} & \multirow{2}{*}{.000 } \\
\hline & Serbia & 97.40 & 15.24 & 3.41 & & \\
\hline \multirow[t]{2}{*}{ TAP } & Slovenia & 36.05 & 3.39 & .76 & \multirow{2}{*}{1.455} & \multirow{2}{*}{.154} \\
\hline & Serbia & 34.05 & 5.12 & 1.15 & & \\
\hline \multirow[t]{2}{*}{ SDM } & Slovenia & 185.80 & 13.19 & 2.95 & \multirow{2}{*}{3.093} & \multirow{2}{*}{.004} \\
\hline & Serbia & 171.10 & 16.66 & 3.73 & & \\
\hline \multirow[t]{2}{*}{ PRE } & Slovenia & 58.40 & 2.87 & .64 & \multirow{2}{*}{1.737} & \multirow{2}{*}{.091} \\
\hline & Serbia & 55.75 & 6.19 & 1.38 & & \\
\hline \multirow[t]{2}{*}{ DT } & Slovenia & 56.10 & 5.83 & 1.30 & \multirow{2}{*}{2.321} & \multirow{2}{*}{.026} \\
\hline & Serbia & 51.40 & 6.93 & 1.55 & & \\
\hline VES & Slovenia & 72.90 & 25.17 & 5.63 & 287 & 776 \\
\hline & Serbia & 70.50 & 27.66 & 6.19 & .201 & . \\
\hline PLEZBR & Slovenia & 141.80 & 87.10 & 19.48 & 1239 & 223 \\
\hline & Serbia & 104.75 & 101.49 & 22.69 & 1.259 & . 225 \\
\hline PREKR & Slovenia & 23.75 & 5.95 & 1.33 & -1704 & 097 \\
\hline & Serbia & 30.60 & 16.97 & 3.79 & -1.104 & \\
\hline VAGZ & Slovenia & 25.70 & 31.96 & 7.15 & 3.194 & 003 \\
\hline & Serbia & 2.20 & 7.81 & 1.75 & 3.194 & (.005 \\
\hline NAUTEZ & Slovenia & 3.55 & 2.89 & .65 & 3579 & 001 \\
\hline & Serbia & 1.00 & 1.34 & .30 & 5.519 & (001 \\
\hline VZN & Slovenia & 104.00 & 28.49 & 6.37 & 745 & 461 \\
\hline & Serbia & 80.80 & 136.31 & 30.48 & $.14 \mathrm{~J}$ & 年. \\
\hline SPIBR & Slovenia & 5.40 & 3.20 & .72 & 2766 & 000 \\
\hline & Serbia & 2.50 & 3.43 & .77 & 2.100 & .009 \\
\hline KOLKBR & Slovenia & 30.05 & 12.22 & 2.73 & 4577 & 000 \\
\hline & Serbia & 13.40 & 10.74 & 2.40 & 4.011 & .000 \\
\hline STOJABR & Slovenia & 63.82 & 113.00 & 27.41 & 821 & 417 \\
\hline & Serbia & 40.20 & 57.01 & 12.75 & & \\
\hline MOST & Slovenia & 95.00 & 10.39 & 2.32 & 1008 & 320 \\
\hline & Serbia & 90.00 & 19.60 & 4.38 & 1.008 & .320 \\
\hline MSP & Slovenia & 1.35 & 1.69 & .38 & 1130 & 266 \\
\hline & Serbia & 2.80 & 5.48 & 1.23 & -1.130 & .200 \\
\hline ZSPL & Slovenia & 2.85 & 3.38 & .75 & 000 & 1000 \\
\hline & Serbia & 2.85 & 4.49 & 1.00 & . & 1.000 \\
\hline ZSPD & Slovenia & 3.15 & 3.73 & .83 & -342 & 734 \\
\hline & Serbia & 3.60 & 4.55 & 1.02 & -.342 & .154 \\
\hline
\end{tabular}

In the age goup $9-10$ years we can determine statistically significant differences between both groups in following tests: POL, SDM, VAGZ, NAUTEZ, SPIBR, KOLKBR $(\mathrm{p}<0.01)$ and DT $(\mathrm{p}<0.05)$. In all mentioned tests slovenian gymnasts were better than serbian. Thus, slovenian gymnasts are better in coordination of the whole body movement (POL), leg power (SDM), repetitive power of arms and shoulders (NAUTEZ, SPIBR), muscular endurance of the torso (DT), specific endurance (KOLKBR) and statical power of shoulder girdle and back (VAGZ) (Table 3). 


\section{Results}

Table 4. Descriptive statistics and $t$ test between Slovenian and Serbian gymnasts 11 - 12 years of age Tabulka 4. Výsledky t-testu u jednotlivých položek ve věkové skupině 11 - 12 let gymnastů Slovinska a Srbska

\begin{tabular}{|c|c|c|c|c|c|c|}
\hline TEST & COUNTRY & MEAN & STD & STD ERROR & T VALUE & SIG. T \\
\hline \multirow[t]{2}{*}{ ATV } & Slovenia & 1437.41 & 68.05 & 16.50 & \multirow{2}{*}{1.356} & \multirow{2}{*}{.185} \\
\hline & Serbia & 1405.12 & 70.84 & 17.18 & & \\
\hline \multirow[t]{2}{*}{ ATT } & Slovenia & 359.12 & 55.22 & 13.39 & \multirow{2}{*}{.971} & \multirow{2}{*}{.339} \\
\hline & Serbia & 341.82 & 48.37 & 11.73 & & \\
\hline \multirow[t]{2}{*}{ AKGN } & Slovenia & 59.24 & 14.56 & 3.53 & \multirow{2}{*}{2.230} & \multirow{2}{*}{.033 } \\
\hline & Serbia & 47.00 & 17.32 & 4.20 & & \\
\hline \multirow[t]{2}{*}{ PON } & Slovenia & 71.94 & 8.05 & 1.95 & \multirow{2}{*}{-3.975} & \multirow{2}{*}{.000} \\
\hline & Serbia & 83.88 & 9.41 & 2.28 & & \\
\hline \multirow[t]{2}{*}{ TAP } & Slovenia & 41.94 & 3.17 & .77 & \multirow{2}{*}{3.809} & \multirow{2}{*}{.001} \\
\hline & Serbia & 36.41 & 5.08 & 1.23 & & \\
\hline \multirow[t]{2}{*}{ SDM } & Slovenia & 202.06 & 16.32 & 3.96 & \multirow{2}{*}{1.911} & \multirow{2}{*}{.065} \\
\hline & Serbia & 190.59 & 18.60 & 4.51 & & \\
\hline \multirow[t]{2}{*}{ PRE } & Slovenia & 59.65 & 3.08 & .75 & \multirow{2}{*}{1.292} & \multirow{2}{*}{.205} \\
\hline & Serbia & 58.06 & 4.02 & .98 & & \\
\hline \multirow[t]{2}{*}{ DT } & Slovenia & 62.35 & 7.34 & 1.78 & \multirow{2}{*}{4.375} & \multirow{2}{*}{.000} \\
\hline & Serbia & 52.47 & 5.73 & 1.39 & & \\
\hline VES & Slovenia & 60.12 & 25.40 & 6.16 & 2026 & 033 \\
\hline & Serbia & 78.71 & 23.25 & 5.64 & -2.220 & (035 \\
\hline PLEB & Slovenia & 99.35 & 18.40 & 4.46 & -1856 & 073 \\
\hline & Serbia & 128.71 & 62.55 & 15.17 & -1.850 & (0) \\
\hline VAGS & Slovenia & 5.41 & 11.99 & 2.91 & 1.246 & .222 \\
\hline & Serbia & 1.47 & 5.12 & 1.24 & 1.240 & .222 \\
\hline STO & Slovenia & 44.12 & 11.25 & 2.73 & 741 & 464 \\
\hline & Serbia & 37.24 & 36.60 & 8.88 & .141 & .404 \\
\hline KOLR & Slovenia & 17.35 & 11.99 & 2.91 & -256 & 800 \\
\hline & Serbia & 18.29 & 9.29 & 2.25 & -.250 & .000 \\
\hline $\mathrm{DN}$ & Slovenia & 14.59 & 7.93 & 1.92 & 538 & 594 \\
\hline & Serbia & 13.18 & 7.36 & 1.78 & .508 & . .594 \\
\hline PUMP & Slovenia & 6.53 & 3.76 & .91 & 573 & 571 \\
\hline & Serbia & 5.76 & 4.02 & .98 & (5) & . \\
\hline SALTO & Slovenia & 8.88 & 3.76 & .91 & 3423 & 002 \\
\hline & Serbia & 4.18 & 4.25 & 1.03 & 5.425 & . \\
\hline SPBR & Slovenia & 6.24 & 3.11 & .76 & 2779 & 009 \\
\hline & Serbia & 3.47 & 2.67 & .65 & 2.119 & (007) \\
\hline MOST & Slovenia & 95.29 & 12.68 & 3.08 & 900 & 375 \\
\hline & Serbia & 90.29 & 19.08 & 4.63 & .900 & נונד. \\
\hline MSP & Slovenia & 2.59 & 2.32 & .56 & -098 & 923 \\
\hline & Serbia & 2.71 & 4.37 & 1.06 & -.090 & .920 \\
\hline ZSPL & Slovenia & 4.71 & 3.69 & .89 & 454 & .653 \\
\hline & Serbia & 4.06 & 4.58 & 1.11 & & \\
\hline ZSPD & Slovenia & 5.06 & 4.23 & 1.03 & .361 & .721 \\
\hline & Serbia & 4.53 & 4.32 & 1.05 & . & \\
\hline
\end{tabular}

Statistically significant differences between serbian and slovenian gymnasts $11-12$ years of age are in the tests: PON, TAP, DT, SALTO, SPIBR ( $p<0.01)$ and AKG and VES ( $p<0.05)$. The best slovenian gymansts in this age group are achieving better results than their serbian contemporaries in the tests of coordination of the whole body movement (PON), speed of alternate movement (TAP), leg power and coordination (SALTO), repetitive power of shoulder girdle and arms (SPIBR) and also muscular endurance of the torso (DT). The best serbian gymnasts have in compare to the slovenian gymnasts lower amount of body fat (AKGN) and higher muscular endurance of shoulder girdle and arms (VES) (Table 4). 
Table 5. Descriptive statistics and $t$ test between Slovenian and Serbian gymnasts 13 - 14 years of age Tabulka 5. Výsledky t-testu u jednotlivých položek ve věkové skupině 13 - 14 let gymnastů Slovinska a Srbska

\begin{tabular}{|c|c|c|c|c|c|c|}
\hline TEST & COUNTRY & MEAN & STD & STD ERROR & T VALUE & SIG. T \\
\hline \multirow[t]{2}{*}{ ATV } & Slovenia & 1696.90 & 53.48 & 16.91 & \multirow{2}{*}{8.066} & \multirow{2}{*}{.000} \\
\hline & Serbia & 1487.00 & 62.55 & 19.78 & & \\
\hline \multirow[t]{2}{*}{ ATT } & Slovenia & 680.40 & 64.29 & 20.33 & \multirow{2}{*}{10.033} & \multirow{2}{*}{.000} \\
\hline & Serbia & 396.90 & 62.06 & 19.63 & & \\
\hline \multirow[t]{2}{*}{ AKGN } & Slovenia & 61.90 & 21.67 & 6.85 & \multirow{2}{*}{1.904} & \multirow{2}{*}{.073} \\
\hline & Serbia & 48.10 & 7.49 & 2.37 & & \\
\hline \multirow[t]{2}{*}{ POL } & Slovenia & 60.50 & 3.81 & 1.20 & \multirow{2}{*}{-5.793} & \multirow{2}{*}{.000} \\
\hline & Serbia & 76.90 & 8.10 & 2.56 & & \\
\hline \multirow[t]{2}{*}{ TAP } & Slovenia & 51.60 & 4.50 & 1.42 & \multirow{2}{*}{5.128} & \multirow{2}{*}{.000} \\
\hline & Serbia & 41.10 & 4.65 & 1.47 & & \\
\hline \multirow[t]{2}{*}{ SDM } & Slovenia & 259.60 & 13.57 & 4.29 & \multirow{2}{*}{9.154} & \multirow{2}{*}{.000} \\
\hline & Serbia & 201.70 & 14.69 & 4.65 & & \\
\hline \multirow[t]{2}{*}{ PRE } & Slovenia & 65.00 & 3.53 & 1.12 & \multirow{2}{*}{5.399} & \multirow{2}{*}{.000} \\
\hline & Serbia & 56.80 & 3.26 & 1.03 & & \\
\hline \multirow[t]{2}{*}{ DT } & Slovenia & 68.50 & 6.10 & 1.93 & \multirow{2}{*}{4.462} & \multirow{2}{*}{.000} \\
\hline & Serbia & 52.60 & 9.48 & 3.00 & & \\
\hline \multirow[t]{2}{*}{ VES } & Slovenia & 40.80 & 23.60 & 7.46 & -3607 & 002 \\
\hline & Serbia & 79.40 & 24.25 & 7.67 & -3.007 & \\
\hline PLEZB & Slovenia & 48.20 & 4.71 & 1.49 & 6598 & 000 \\
\hline & Serbia & 153.00 & 50.01 & 15.81 & -0.598 & .000 \\
\hline VAGS & Slovenia & 43.50 & 28.73 & 9.09 & 3444 & 003 \\
\hline & Serbia & 6.00 & 18.97 & 6.00 & 3.444 & . \\
\hline STOJKR & Slovenia & 39.60 & 12.84 & 4.06 & 7833 & 000 \\
\hline & Serbia & 5.80 & 4.61 & 1.46 & 1.055 & \\
\hline CKOL & Slovenia & 21.70 & 7.15 & 2.26 & 2648 & 016 \\
\hline & Serbia & 11.80 & 9.41 & 2.98 & 2.648 & (.016 \\
\hline PUMP & Slovenia & 13.80 & 3.65 & 1.15 & 6160 & 000 \\
\hline & Serbia & 4.10 & 3.38 & 1.07 & 0.109 & .000 \\
\hline SALTO & Slovenia & 13.40 & 2.01 & .64 & 5.469 & 000 \\
\hline & Serbia & 5.10 & 4.36 & 1.38 & & \\
\hline SPIKR & Slovenia & 5.20 & 1.87 & .59 & 6115 & 000 \\
\hline & Serbia & .90 & 1.20 & .38 & 0.115 & .000 \\
\hline MOST & Slovenia & 75.00 & 20.28 & 6.41 & -1606 & 126 \\
\hline & Serbia & 90.00 & 21.47 & 6.79 & -1.000 & .120 \\
\hline MSP & Slovenia & 8.10 & 7.36 & 2.33 & 113 & 911 \\
\hline & Serbia & 7.70 & 8.42 & 2.66 & .113 & 911 \\
\hline ZSPL & Slovenia & 7.50 & 6.50 & 2.06 & 1130 & 270 \\
\hline & Serbia & 4.00 & 7.23 & 2.29 & 1.139 & .270 \\
\hline ZSPD & Slovenia & 8.60 & 8.34 & 2.64 & 1150 & 265 \\
\hline & Serbia & 4.90 & 5.82 & 1.84 & 1.150 & .263 \\
\hline
\end{tabular}

In this age groupe (13 - 14 years) we found out the most of the differences between serbian and slovenian groups of gymansts (Table 5). All the differences were significant at the very high level $(p<0.01)$. Slovenian gymnasts had better results in all of those tests. These are: coordination of the whole body movement (PON), speed of alternate movement (TAP), leg power and coordination (SDM, SALTO), flexibility of legs and torso (PRE), arm power (PLEZ), equilibrium and muscular endurance of shoulder girdle and arms (VAGS, STOJKR), repetitive power of shoulder girdle and arms (PUMP, SPIKR), muscular endurance of the torso (DT) and specific endurance (CKOL). Slovenian gymnasts in this age group are also taller, weigh more and have higher amount of body fat but without significant differences. Serbian gymnasts are better in muscular endurance of shoulder girdle and arms (VES) $(\mathrm{p}<0.01)$. 


\section{Discussion}

While helping to develop young gymnasts coaches have to be very systematical. They have to be aware that development of motor abilities is one of the most important issues in coaching young children. Only well physically prepared gymnasts will be able to perform gymnastic elements and routines technically correct and without any unnecessary injuries. Therefore, it is highly important to dedicate enough time to the development of motor abilities.

Apart from motor abilities there are also physical characteristics that have an important effect on motor efficiency. Coaches can change these characteristics with suitable practice.

In order to find out which physical characteristics and motor abilities serbian gymnasts differ from slovenian gymnasts we made this research. From the results we can conclude:

1. Statistically significant differences between serbian and slovenian gymnasts exist in 19 out of 35 variables.

2. Statistically significant differences are mostly in favour of slovenian gymnasts. Serbian gymnasts achieved significantlly better results only in two tests (VES and AKGN).

3. Slovenian gymnasts achieved better results in most of the tests:

-fast power of legs and arms (SDM, PLEZBN, SALTO)

-(continuous) musculare endurance of the torso (DT) and the shoulder girdle and arms (SPIBR, SPIKR, PUMP, NAUTEZ)

-(static) musculare endurance (OPORKR, VAGZ, VAGS, STOJKR)

-specific endurance (KOLKBR, CKOL)

-coordination of the whole body movement (PON) and speed of alternate movement (TAP)

4. In flexibility there is just one significant difference between the mean values of the groups (PRE; 13 - 14 years). We can conclude that for this subsistem of motor abilities gymnasts from both groups are prepared at the same level.

The reason for the difference between nations is probably due to the longer tradition of top-level gymnastics in Slovenia. As the sport systems develop through a longer period of time, tradition in sport plays a very important role.

In order to take advantage of young gymnasts' potential we have to make it possible that every coach in the country gets the opportunity to develope his/her knowledge of sport science and coaching. Expert and research advanced study courses are one of the ways to spread knowledge. Only in such case we will truely help all gymnasts in the country to develope their sport (not only motor) potential.

\section{REFERENCES}

Crnjac R. (1998). Norme nekaterih motoricnih sposobnosti in morfoloskih znacilnosti za spremljanje ucinkov treniranja pri deckih 6-14 let $v$ sportni gimnastiki. Bachelor's thesis. Ljubljana: Univerza v Ljubljani, Fakulteta za sport.

Cuk. I, Kolar E., Crnjac R., Piletic S. (1997). Spremljanje nekaterih ucinkov treniranja sportne gimnastike na motoricne sposobnosti in morfoloske znacilnosti deckov starih $6-14$ let. Ljubljana: Gimnasticna zveza Slovenije.

Kolar E., Cuk I. (1999). Vrednotenje potencialnega modela uspesnosti (motoricni in morfoloski prostor) za decke kategorije 6-8 let $\mathrm{v}$ moski sportni gimnastiki. In Cuk, I. \& Kolar, E. (Eds.), Strokovni prirocnik st. 8 (p. $65-78$ ). Ljubljana: Gimnasticna zveza Slovenije.

Piletic S., Kolar E., Cuk I. (1997). Strokovni prirocnik st. 6. Ljubljana: Gimnasticna zveza Slovenije.

\author{
MSc Miha Marinsek \\ Gregorciceva 33 \\ 2000 Maribor \\ Slovenia \\ Telephon number: +38641 955103 \\ e-mail: miha.marinsek@gmai1.com
}

